\title{
Use of Active Powder to Improve Carrying Capacity Vertisol And Alfisol on Dry Land Farming System
}

\author{
IN Prijo Soetedjo \\ Agriculture Faculty \\ University of Nusa Cendana Kupang \\ Nusa Tengara Timur, Indonesia \\ prijo_2005@yahoo.com
}

\begin{abstract}
Active powder is a innovation product to improve soil microbiology activity which is finally might improve the availability of soil nutrients. Research had been done to know the effect of various dosage of powder active to improve physical and chemical characteristic of vertisol and alfisol at dry land farming system in Kupang, Nusa Tenggara Timur. The research was a factorial research designed as Randomized Completed Block Design replicated 4 times. Variables of the research were two type of soil (vertisol and alfisol) and various dosage of active powder (0, 100,200 , and $300 \mathrm{~g} / \mathrm{ha}$ ). Parameters observed were analyzed by Analysis of Variant and followed by Least Significant Different Test at 0.05 level Results of the research showed that dosage active powder of $300 \mathrm{~g} / \mathrm{ha}$ were able to improve number colony of soil bacteria, improve in soil porosity, soil bulk density, total $\mathrm{N}$, availability of $P$, and availability of $K$. Generally, physical and chemical characteristic of vertisol improved greatly than alfisol. Yield of mungbean was significantly affected by dosage application of powder active by $200-300 \mathrm{~g} / \mathrm{ha}$ in which yield of mungbean grown at vertisol was higher than yield of mungbean grown at alfisol.
\end{abstract}

Keywords- dosage, powder active, physical and chemical characteristic of soil, yield of mungbean

\section{INTRODUCTION}

Alfisol and vertisol are two kinds of soil dominated on dry land farming system such as in East Nusa Tenggara. Alfisol has low nutrients content such as $\mathrm{N}, \mathrm{P}, \mathrm{K}, \mathrm{C}$ organic, Mo, Mg, and poisoning of $\mathrm{Al}, \mathrm{Fe}$, and $\mathrm{Mn}$. Moreover, alfisol has medium to high of bulk density, less to medium soil of permeabilility, low of water soil resistance, high sensivity of erosion, and low content of soil microbiology. Similarly, vertisol has low content of some nutrients such as N, P, K, C organic, dominated by clay, high water saturated as in [1], [2], and [3]. Those conditions resulted low capabilities of the soil in supporting growth and yield of crop. Numerous ways have been practiced improving capabilities of vertisol and alfisol such as applying an organic and organic fertilizer. However, some studies showed that those practices resulted on increasing of soil compaction, and increasing of soil microbiology dormantion as in [4] and [5]. Meanwhile, activities of soil microbiology are needed to improve physical soil characteristic and improve availability of some soil nutrients. Some studies showed that organic fertilizer could improve availability of soil microorganism and could improve the availability of nutrients such as nitrogen, phosphorus, and potassium [6] and [7]. However, it needs huge number of organic fertilizer source which is about 10-20 t/ha. It would be a serious problem at dry land farming system practices which is generally low sources of organic matter and less man power. Therefore, it should be found an innovation technology that could minimize use of organic sources, but, it could improve physical and chemical characteristic of soil. Active powder is one of an innovation product that is available to improve soil microbiology activities which improve availability of some soil nutrients. Physically, active powder may able to increase maximally the use of gamma radiation to increase number of oxygens into soil. Gamma radiation is able to intercept into $50 \mathrm{~cm}$ soil depth in which increase degradation $\mathrm{H}_{2} \mathrm{O}$ processes become hydrogen $\left(\mathrm{H}_{2}\right)$ and oxygen $\left(\mathrm{O}_{2}\right)$. Increasing in oxygen level into the soil will affect to increased activity of soil microorganism and biomass of microorganism. These processes may stimulate improvement of soil structure, improve soil aeration, improve exchange capacity of anions and cations, and improve availability of nutrients. However, these positive effects of active powder application will strongly depend on soil type, dosage application, time application, and plant growth. This is mainly due to various type of soil have different physical and chemical characteristics as reported by [8] and [9]. Some type of soil has high contents of clay with low some nutrients content and others have low content of clay and enough some nutrients content. Based on those studies, it will give more information if application powder active is examined in detail at various soil types, and various dosage applications.

\section{METHODS}

Present research was conducted at Naibonat Village (dominated by vertisol) and Matani Village (dominated by alfisol), district of Kupang, East Nusa Tenggara Province since May to October 2017. Factorial research was designed on Randomized Complete Block Design with four replications. Variable of the research were two type of soil (vertisol and alfisol) and various dosage of active powder $(0,100,200$, and $300 \mathrm{~g} / \mathrm{ha})$. Parameters observed of the research were number of colony soil bacteria, nutrients content (Nitrogen, Phosphorus, Potassium, C organic), and yield of mungbean. Results of the parameters observed were analyzed by Analysis of Variant and followed by Least Significant Different 0.05 level to compare the treatments means. 


\section{RESULTS AND DISCUSSION}

\section{A. Colony Soil Bacteria}

Result of the research showed that increasing in dosage application of active powder up to $300 \mathrm{~g} / \mathrm{ha}$ resulted an increasing of colony soil bacteria (Table 1) on both of soil type (vertisol and alfisol). This is mainly due to those soils have a content of clay, low of soil porosity and high bulk density. These conditions result in low oxygen content that it is highly required by soil microorganism activities. By application active powder up to $300 \mathrm{~g} / \mathrm{ha}$, more oxygen may able to increase number and activities of soil microorganism result to improvement soil porosity, improve soil aeration, decreasing in bulk density, and improvement of cation exchangeable capacity. A number of studies reported that availability of soil microorganism depend strongly to microclimate condition of the soil such as $\mathrm{pH}$, aeration, energy sources and soil management as in [10], [11], and [12].

Table1.The effect of various dosage of active powder application to number of soil bacteria

\begin{tabular}{l|c|l|ll}
\hline \multirow{2}{*}{ Dosage (g/ha) } & \multicolumn{2}{|c|}{$\begin{array}{c}\text { Number of Colony Soil } \\
\text { Bacteria }\end{array}$} & \multirow{2}{*}{ Changeable } \\
\cline { 2 - 3 } & Before & After application & & \\
\hline 0 & 236.5 & $233.50 \mathrm{a}$ & 3 & $\mathrm{a}$ \\
100 & 236.5 & $271.37 \mathrm{~b}$ & 34.87 & $\mathrm{~b}$ \\
200 & 236.5 & $285.25 \mathrm{bc}$ & 48,75 & $\mathrm{bc}$ \\
300 & 236.5 & $292.87 \mathrm{c}$ & 53,37 & $\mathrm{c}$ \\
\hline LSD 5\% & & 15.23 & 15.23 & \\
\hline
\end{tabular}

Number followed by same letter at the same column means not significantly different at LSD $5 \%$ level.

Moreover, the research showed that number of colony bacteria was higher at vertisol than alfisol (Table 2). This is mainly due to/centage of porosities on vertisol relatively higher than alfisol at all various dosage of powder active applications. As a result, its affect significantly to an increase of oxygen level and increase source of energy that are required by soil microorganism activities. References [10], [12], and [13], reported that availability of nutrients, well aeration and drainage, better source of energy (solar radiation and organic matter) are a number of factors that should be taken account to improve growth and development of soil microorganism

Table 2. Number of soil bacteria at different soil type affected

\begin{tabular}{|c|c|c|c|}
\hline \multirow[t]{2}{*}{ Soil type } & \multicolumn{2}{|c|}{ Number of Colony Soil Bacteria } & \multirow[t]{2}{*}{ Changeable } \\
\hline & Before & After application & \\
\hline Vertisol & 261.5 & $277.63 \mathrm{~b}$ & $25.68 \mathrm{a}$ \\
\hline Alfisol & 211.5 & $263.88 \mathrm{a}$ & $52.38 \mathrm{~b}$ \\
\hline BNT 5\% & & 10.77 & 10.77 \\
\hline
\end{tabular}

\section{B. Soil Porosity}

Result of the research showed that active powder application affects significantly to soil porosity. It showed that $100-300$ $\mathrm{g} / \mathrm{ha}$ active powder applications resulted in increase in soil porosity of vertisol and alfisol compared to no application of active powder (Table 3 ). These results showed that active powder is able to improve oxygen level on the soil resulted increasing in soil microorganism activities to improve soil porosities, soil aeration, and decrease bulk density. Moreover, improvement soil porosities of vertisol was higher than soil porosities of alfisol. Some studies as in [3], [10], [14], and [15] reported that activities and biomass organism increase significantly to soil which low clay content than high clay content (Table 4).

Table 3.The effect of various dosage of active powder application to soil porosity

\begin{tabular}{|c|c|c|c|c|c|}
\hline \multirow[t]{2}{*}{$\begin{array}{l}\text { Dosage } \\
\text { (g/ha) }\end{array}$} & \multicolumn{3}{|c|}{$\begin{array}{l}\text { Soil Porosity Affected by } \\
\text { Active Powder Application }\end{array}$} & \multirow{2}{*}{\multicolumn{2}{|c|}{ Changeable }} \\
\hline & Before & After a & ication & & \\
\hline 0 & 59.65 & 58.81 & $\mathrm{a}$ & -0.84 & A \\
\hline 100 & 59.65 & 62.97 & $\mathrm{~b}$ & 3.32 & B \\
\hline 200 & 59.65 & 63.06 & $\mathrm{~b}$ & 3.41 & B \\
\hline 300 & 59.65 & 64.97 & $\mathrm{~b}$ & 5.32 & B \\
\hline LSD 5\% & & 3.39 & & 3.39 & \\
\hline
\end{tabular}

Table 4. Soil porosity at different soil type affected by various dosage application

\begin{tabular}{l|l|l|l}
\hline \multirow{2}{*}{ Soil type } & \multicolumn{2}{|c|}{$\begin{array}{c}\text { Soil Porosity Affected by } \\
\text { Active Powder Application }\end{array}$} & \multirow{2}{*}{ Changeable } \\
\cline { 2 - 3 } & Before & After application & \\
\hline Vertisol & 55.01 & $60.73 \mathrm{a}$ & $5.74 \mathrm{~b}$ \\
\hline Alfisol & 64.3 & $64.15 \mathrm{~b}$ & $-0.14 \mathrm{a}$ \\
\hline LSD 5\% & & 2.40 & 2.40 \\
\hline
\end{tabular}

Number followed by same letter at the same columnmeans not significantly different at LSD $5 \%$ level.

\section{Total Nitrogen Content}

Theres was no interaction effect of dosage and type of soil to nitrogen content. However, single variable of dosage and type of soil affcetd significantly to nitrogen content. LSD test at level $5 \%$ showed that powder active application to $300 \mathrm{~g} / \mathrm{ha}$ resulted an increasing in nitrogen content of both type of soil in which an increasing nitrogen content on vertisol significantly higher than nitrogen content on alfisol (Table 5).

Table 5. Single effect of active powder application and type of

\begin{tabular}{|c|c|c|c|c|c|}
\hline $\begin{array}{c}\text { Dosage } \\
\text { (g/ha) }\end{array}$ & $\begin{array}{c}\text { Before } \\
\text { Application }\end{array}$ & \multicolumn{2}{|c|}{$\begin{array}{c}\text { After } \\
\text { Application }\end{array}$} & \multicolumn{2}{|c|}{ Changeable } \\
\hline 0 & 0.067 & 0.57 & $\mathrm{a}$ & 0.51 & $\mathrm{~A}$ \\
\hline 100 & 0.067 & 0.65 & bc & 0.58 & $\mathrm{Ab}$ \\
\hline 200 & 0.067 & 0.66 & $\mathrm{c}$ & 0.59 & $\mathrm{~B}$ \\
\hline 300 & 0.067 & 0.71 & $\mathrm{c}$ & 0.64 & $\mathrm{~B}$ \\
\hline LSD 5\% & & 0.07 & & 0.08 & \\
\hline Vertisol & 0.067 & $0.81 \mathrm{~b}$ & & $0.74 \mathrm{~b}$ & \\
\hline Alfisol & 0.067 & $0.49 \mathrm{a}$ & & $0.42 \mathrm{a}$ & \\
\hline LSD 5\% & & 0.05 & & 0.05 & \\
\hline
\end{tabular}

Number followed by same letter at the same column at different single variable of dosage and type of soil means not significantly different at LSD 5\% level.

An increasing in nitrogen content at $300 \mathrm{~g} / \mathrm{ha}$ of active powder application is mainly due to increase number of microorganism resulted to improvement of soil microbacteria activities, improvent of soil porosity of the soil, decreasing in soil coloid and improvement of cation excangable capasity. A number of studies as in [14], [15], and [16] reported that increase in number and activities of soil microorganism as result of various soil management affect to improvement of availability of some nutrients ( $\mathrm{N}, \mathrm{P}$, and $\mathrm{K}$ ). Improvemnt of vertisol is much more better than alfisol could be related to physical characteristic of vertisol is better ini supporting gamma 
radiation interception into depth of the soil resulted an increase number of soil microorganism on the depth of soil.

\section{Available Phosphorus}

Result analysis variant showed that there was interaction effcet of dosage and type of soil to available phosphorus. Further analysis by LSD 5\% level showed that all dosage active powder application on alfisol resulted higher content of available phosphorus compare to vertisol. (Table 6). This is maily due to a higher content of nitrogen on vertisol suppress amount of phosphorus in the vertisol, instead low content of nitrogen increase available phosphorus on alfisol. Meanwhile, both type of soils has high content of available phosphorus applied by $300 \mathrm{~g} /$ ha of powder active. These results showed that there is significantly correlation between improvement the availability of some nutrients with increase number of soil microorganism, and improvement of porosities and aeration of soil as in [10] and [13]

Table 6. The effect of dosage active powder application interacted type of soil on available Phosphorus content (ppm)

\begin{tabular}{c|l|l|l|l|l|l|l|l}
\hline $\begin{array}{c}\text { Type of Soil/ } \\
\text { Dosage } \\
\text { (g/ha) }\end{array}$ & \multicolumn{2}{|c|}{300} & \multicolumn{2}{c|}{200} & \multicolumn{2}{c|}{100} & \multicolumn{2}{c}{0} \\
\hline \multirow{2}{*}{ Vertisol } & 16.09 & b & 15.88 & ab & 15.422 & ab & 14.81 & a \\
\cline { 2 - 11 } & A & & A & & A & & A & \\
\hline \multirow{2}{*}{ Alfisol } & 22.71 & b & 21.64 & ab & 20.38 & ab & 19.427 & a \\
\cline { 2 - 10 } & B & & B & & B & & B & \\
\hline
\end{tabular}

Number that followed by same small letter at the same row and capital letter at the same colomn means not significantly different at LSD $5 \%$ level.

\section{E. Potassium Content}

Table 7. Single effect of active powder application and type of soil to Potassium content of the soil (me/100g)

\begin{tabular}{|c|c|c|c|c|c|}
\hline $\begin{array}{l}\text { Dosage } \\
\text { (g/ha) }\end{array}$ & $\begin{array}{c}\text { Before } \\
\text { Application }\end{array}$ & \multicolumn{2}{|c|}{$\begin{array}{c}\text { After } \\
\text { Application }\end{array}$} & \multicolumn{2}{|c|}{ Excangable } \\
\hline 0 & 0.66 & 0.69 & $\mathrm{a}$ & 0.03 & $\mathrm{a}$ \\
\hline 100 & 0.66 & 0.99 & $\mathrm{~b}$ & 0.34 & $\mathrm{a}$ \\
\hline 200 & 0.66 & 1.07 & $\mathrm{bc}$ & 0.41 & $\mathrm{~b}$ \\
\hline 300 & 0.66 & 1.16 & $\mathrm{c}$ & 0.50 & B \\
\hline LSD $5 \%$ & & 0.11 & & 0.11 & \\
\hline Vertisol & 1.21 & $1.20 \mathrm{~b}$ & & $-0.02 \mathrm{a}$ & \\
\hline Alfisol & 0.11 & $0.75 \mathrm{a}$ & & $0.65 \mathrm{~b}$ & \\
\hline LSD $5 \%$ & & 0.08 & & 0.05 & \\
\hline
\end{tabular}

Number followed by same letter at the same column at different single variable of dosage and type of soil means not significantly different at LSD $5 \%$ level.

Result of the research showed that there was no interaction effect of dosage active powder application and type of soil to potassium content. However, single factor of those variables resulted to increase in potassium content of the soil. Application of 200-300 g/of active powder increased significantly potassium content of both type of soil, meanwhile, potassium content of vertisol increased higher than alfisol (Table 7). All the result showed that improvement of physical characteristic of the soil govern directly to nutrients content of the soil. A better increase in soil porosity result an icrease in number of soil microorganism and their activies stimulate an increase cation excangable capacity and aavailable of nutrients.

\section{F. C Organic content}

Result of the rearch showed that there was no interaction affect to $\mathrm{C}$ organic content. However, single factor type of soil affected significantly to $\mathrm{C}$ organic content. It showed that increasing in $\mathrm{C}$ organic content of alfisol was higher than vertisol. It is mainly due to vertisol has a high clay textured soil than alfisol. Also, increasing in nitrogen content affected by powder active application could affect to decreasing in $\mathrm{C}$ organic content (Table 8). Number of studies showed that physical characteristic of soil (texture, structure, aeration, bulk density) and chemicals characteristic of soil (total $\mathrm{N}$ content) relate closely to $\mathrm{C}$ organic content. High clay textured soil such as vertisol has a low $\mathrm{C}$ organic content and a high content of $\mathrm{N}$ on vertisol will suppress the organic content as reported by [6], [10], and [13].

Table 8 . Single effect of type of soil to $\mathrm{C}$ organic content of the soil $(\%)$ affected by active powde application

\begin{tabular}{l|l|l|l}
\hline Type of Soil & $\begin{array}{c}\text { Before } \\
\text { Application }\end{array}$ & $\begin{array}{c}\text { After } \\
\text { Application }\end{array}$ & Exchangable \\
\hline Vertisol & 1.26 & $0.44 \mathrm{a}$ & $-8.11 \mathrm{a}$ \\
Alfisol & 1.05 & $1.15 \mathrm{~b}$ & $0.11 \mathrm{~b}$ \\
\hline LSD 5\% & & 0.53 & 0.56 \\
\hline
\end{tabular}

Number followed by same letter at the same column means not significantly different at LSD $5 \%$ level.

\section{G. Yield of Mungbean}

Result of the research showed that yield of mungbean was significantly affected by single variable of dosage application of active powder and type of soil. Application of $200-300 \mathrm{~g} / \mathrm{ha}$ active powder resulted a higher yield of mungbean $\left(\mathrm{g} / 6 \mathrm{~m}^{2}\right)$ compared to no application of active powder. Moreover, yield of mungbean on vertisol was higher than yield of mung bean on alfisol. All these result mainly due improvement of physical charactersitic and chemichal characteristic of the vertisol after application of active powder better than alfisol.

Table 9. Single effect of active powder application and type of soil to yield of mungbean $\left(\mathrm{g} / 6 \mathrm{~m}^{2}\right)$

\begin{tabular}{l|c|cc}
\hline Dosage (g/ha) & Before Application & After Application of Active \\
Powder
\end{tabular}

Number followed by same letter at the same column at different single variable of dosage and type of soil means not significantly different at LSD $5 \%$ level.

\section{CONCLUSION}

It can concluded that application of active powder significantly affect to improvement of physical and chemichal characteristic of vertisol and alfisol. Application $300 \mathrm{~g} / \mathrm{ha}$ of active powder resulted a better physical and chemichal characteristic of vertisol and alfisol in which vertisol is much more better that alfisol. A higher yield of mungbean is $225 \mathrm{~g} / 6$ $\mathrm{m}^{2}$ affected by application of $300 \mathrm{~g} /$ ha powder active. 


\section{REFERENCES}

[1] K.A. Hanafiah, A. Napoleon and N. Ghofar, Biologi Tanah, Ekologi dan Mikrobiologi Tanah.

[2] S. H. Hardjowigeno, Ilmu Tanah, Jakarta: Akademikan Pressindo, 2015.

[3] Serangmo, "Kajian Beberapa Sifat Fisik Tanah Vertisol dan Alfisol akibat Pemberian Tiga Macam Bahan Dasar pupuk Orga-dec serta Hasil Baby Buncis," Buletin Leguminosae, vol. 12, no. 2, 2015.

[4] P. A.K. Ramli and U. A. Rajamudin, "Perubahan Sifat Fisik Tanah Akibat Pemberian Pupuk Kandang dan Mulsa Pada /tanaman Terong Ungu (Solanum melongea L), Entisol, Tondo Palu," e J Agrotekbis 4, vol. 2, pp. 160-167, 2016.

[5] S. Muyasir and I. Saputra, "Perubahan Sifat Fisik Inceptisol Akibat Perbedaan Jenis dan Dosis Pupuk Organik," Jurnal LENTERA, vol. 12, no. $1,2012$.

[6] I. Mertikawati, A.D. Suyono and S. Sjakasutami, "Pengaruh Berbagai Pupuk OrganikTerhadap Beberapa Sifat Fisik, Kimia Vertisol dan Ultisol serta Hasil Padi Gogo," in Kongres Nasional VII HITI, Bandung, 2012.

[7] S.A. Zannah, G. Budiyanto and D. Mulyono, Pemanfaatan Bahan Organik Dalam /baikanBeberapa Sifat Tanah Pasir Pantai Selatan Kulon Progo, Yogyakarta: Faperta UMY, 2014.

[8] A. Tangketasik, N. M. Wikarniti, N. N. Soniari and I. W. Narka, "Kadar Bahan Organik Tanah Pada Tanah Sawah dan Tegelan di Bali Serta Hubungannya dengan Tekstur Tanah," Agrotrop, vol. 2, no. 2, pp. 101107, 2012.

[9] N. M. Y. Hakim, A. M. Nyakpa, S. G. M. R. Lubis, S. Nugroho, M.A. Diha, G. B. Hong and H. H. Baily, Dasar-Dasar Ilmu Tanah, Jakarta: Raja Grafindo, 2014.

[10] Hassink, "Effect of soil texture on the size of the microbial biomass and on the amount of $\mathrm{C}$ and $\mathrm{N}$ mineralized/unit of microbial biomass in Dutch grassland soils," Biochem, vol. 26, pp. 1573-1581, 1994.

[11] M. Irfan, "Isolasi dan Enumerasi Bakteri Tanah Gambut di Perkebunan Kelapa Sawit PT Tambang Hijau Kecamatan Tambang Kabupaten Kampar," Agroteknologi, vol. 1, pp. 1-8, 2014.

[12] A. Iswandi, D.A. Santoso and R. Widyastuti, "Penggunaan Ciri Mikroorganisme Dalam Mengevaluasi Degradasi Tanah," in Kongres Nasional VI HITI, Serpong, 1995.

[13] Fitri, "Makrofauna dan Mikrofauna dalam Sifat Fisik dan Kimia Tanah," 2011. [Online]. Available: http://fitr i05.wordpress.com/2011/01/24//anmakroba fauna-dan-mikrofauna-dalam-sifat-fisik-dan-kimia-tanah/ . [Accessed 4 August 2018].

[14] D. M. Granatstein, D. B. D.M., V. L. Cohran, L.F. Gillot and J. Hammel, "Long Term Tillage and Rotation Effects on Soil Microbial Biomass, Carbon, And Nitrogen," Biol Fertil Soil, vol. 5, pp. 265-270, 1987.

[15] I. P. Soetodjo, "Study The Use of Straw Paddy as Mulch to Improve Water Use Efficiency and Soil Nutrients Content," Journal of Dry Land Farming System, vol. 16, pp. 31-38, 2008.

[16] D. Beja, WII Mella and S. P, "Sistem Tebas Bakar dan Pengaruhnya Terhadap Komponen Fisik Kimia Tanah serta Vegetasi pada Ladang dan Lahan Bera( Studi Kasus di Desa Pruda Kecamatan Waiblama Kabupaten Sikka Provinsi Nusa Tenggara Timur," 2015. 